\title{
Effects of wheat supplementation levels on growth performance, blood profiles, nutrient digestibility, and pork quality in growing-finishing pigs
}

\author{
Tae Hee Han', Jin Su Hong ${ }^{1}$, Lin Hu Fang ${ }^{1}$, Sung Ho Do ${ }^{1}$, Byung Ock Kim, and Yoo Yong Kim,*
}

\begin{abstract}
* Corresponding Author: Yoo Yong Kim Tel: +82-2-878-5838, Fax: +82-2-878-5839, E-mail: yooykim@snu.ac.kr
\end{abstract}

'School of Agricultural Biotechnology, Seoul National University, Seoul 08826, Korea

Submitted Oct 24, 2016; Revised Dec 13, 2016; Accepted Jan 28, 2017
Objective: This study was conducted to evaluate various wheat supplementation levels on growth performance, blood profiles, nutrient digestibility, and pork quality in growing-finishing pigs.

Methods: A total of 120 growing pigs ([Yorkshire $\times$ Landrace] $\times$ Duroc), with an average $27.75 \pm$ $1.319 \mathrm{~kg}$ body weight, were used in growth trial. Pigs were allotted into each treatment by body weight and sex in 4 replicates with 6 pigs per pen in a randomized complete block design. Fourphase feeding programs were used in this experiment. The treatments included the following: i) corn-soybean meal (SBM) - based diet (CON), ii) corn-SBM - based diet $+15 \%$ of wheat (W15), iii) corn-SBM - based diet $+30 \%$ of wheat (W30), iv) corn-SBM - based diet $+45 \%$ of wheat (W45), and 5) corn-SBM-based diet $+60 \%$ of wheat (W60).

Results: There was no significant difference in growth performance among the dietary treatments. However, the gain-to-feed (G:F) ratio tended to increase (quadratic, $p<0.08$ ) when the pigs were fed a higher wheat diet during the finishing period. The digestibility of crude ash and fat tended to decrease as the wheat supplementation level increased $(\mathrm{p}<0.08)$. The proximate analysis of the longissimus muscle was not affected by the dietary level of wheat. The crude ash content in pork was decreased linearly as the wheat supplementation level increased $(\mathrm{p}=$ 0.05). There was no significant difference in the $\mathrm{pH}$ level, shear force, water holding capacity, and cooking loss of the pork. In pork and fat, $\mathrm{L}^{\star}, \mathrm{a}^{\star}$, and $\mathrm{b}^{\star}$ values were not significantly different among dietary treatments.

Conclusion: Wheat can be supplemented up to $60 \%$ in a growing-finishing pig without detrimental effects on growth and pork quality. The G:F ratio tended to improve in the finishing period by wheat inclusion.

Keywords: Wheat; Growth Performance; Blood Profile; Nutrient Digestibility; Growing-finishing Pigs

\section{INTRODUCTION}

Wheat is the most widely used ingredient in the European Union (EU), with barley [1] subsequently being supplemented in swine diets as with corn in Korea. The concentration of gross energy in wheat is $91 \%$ to $97 \%$ relative to corn when used in pigs [2,3]. However, crude protein (CP) and amino acids concentration such as lysine, tryptophan, and threonine are higher in wheat than in corn [3]. Crude fiber, neutral detergent fiber (NDF) and acid detergent fiber (ADF) concentration in wheat is higher than in corn [3]. Wheat contains less starch [2] and more non-starch polysaccharides (NSP) than corn [4]. High levels of soluble NSP are known as the factor that increases the viscosity of digesta in birds but it is not a limiting factor in pigs because they have a longer retention time of digesta [2]. Wheat does have a relatively higher phosphorous digestibility and total calcium concentration than corn $[2,3]$. Wheat can be infected with deoxynivalenol 
and zearlenone which are representative mycotoxins when it has high moisture and temperature [2].

When pigs were fed wheat-based diets, growth performance improved and similar pork quality was observed when compared with pigs fed corn-based diets if nutrient requirements were equal [5]. Cromwell [6] reported that wheat could be entirely substituted for corn in the diet from the weaning to finishing period, as long as the diets were balanced for protein and amino acids. In addition, phosphorus digestibility was greater in wheat than in corn because of the presence of endogenous phytase in wheat [3], but it is less efficient in degrading the phosphorus that is bound to the phytic acid [7]. Phosphorus digestibility can be increased in wheat-based swine diets with phytase supplementation and up to 1,000 phytase unit (FTU) of exogenous phytase may be used [2]. For this reason, growth performance and carcass quality of swine fed wheat-based diets are expected to be similar to that of corn-based diets. Therefore, utilizing wheat in the feed industry could be increased, particularly in 2016 [8].

Consequently, this experiment was conducted to investigate the influence of various levels of dietary wheat on growth performance, blood profiles, nutrient digestibility and pork quality in growing-finishing pigs.

\section{MATERIALS AND METHODS}

\section{Experimental animals and management}

All experimental procedures involving animals were conducted in accordance with the Animal Experimental Guidelines provided by the Seoul National University Institutional Animal Use and Care Committee (SNUIAUCC; SNU-160513-1). A total of 120 crossbred ([Yorkshire $\times$ Landrace]) $\times$ Duroc) pigs $(27.75 \pm 1.319 \mathrm{~kg}$ body weight [BW]) were allotted to one of five treatments considering sex and initial BW in 4 replications with 6 pigs per pen in a randomized complete block design. The pen was a fully concrete floor facility $\left(2.60\right.$ by $\left.2.84 \mathrm{~m}^{2}\right)$ in the experimental period, equipped with a feeder and water nipple to provide feed and water ad-libitum during experimental periods, and was in an environmentally controlled facility in Seoul National University Farm. The experimental period lasted 11 weeks and consisted of 4 phases: phase 1 was weeks 1 to 3 , phase 2 was weeks 4 to 6 , phase 3 was weeks 7 to 9 , and phase 4 was weeks 10 to 11 . The BW and feed intake data were collected at the end of each phase in order to calculate the average daily gain (ADG), average daily feed intake (ADFI), and gain-to-feed (G:F) ratio. An allotment of feed to all of the pigs was recorded each day, and waste feed left in the feeder was recorded at the end of each phase. There was no mortality or any health problem during whole experimental periods.

\section{Dietary treatments}

Dietary treatments were different levels of wheat (Table 1): i) cornsoybean meal (SBM) based diet (CON), ii) corn-SBM based diet+ wheat 15\% (W15), iii) corn-SBM based diet+wheat 30\% (W30),
Table 1. Chemical composition of corn and wheat (as dry matter basis)

\begin{tabular}{lcc}
\hline Item & Corn & Wheat \\
\hline $\begin{array}{l}\text { Analyzed chemical composition } \\
\text { Crude protein (\%) }\end{array}$ & 6.89 & 11.25 \\
Essential amino acids (\% of protein) & & \\
Arg & 0.32 & 0.50 \\
His & 0.20 & 0.25 \\
Ile & 0.26 & 0.36 \\
Leu & 0.87 & 0.72 \\
Lys & 0.20 & 0.28 \\
Met & 0.14 & 0.17 \\
Phe & 0.34 & 0.51 \\
Thr & 0.26 & 0.34 \\
Val & 0.35 & 0.43 \\
Non-essential amino acids (\% of protein) & & \\
Ala & 0.52 & 0.39 \\
Cys & 0.17 & 0.25 \\
Gly & 0.26 & 0.44 \\
Ser & 0.35 & 0.52 \\
Tyr & 0.29 & 0.34 \\
Fiber (\%) & & \\
ADF & & 3.60 \\
NDF & 2.50 & 11.66 \\
\hline ADF acid & 8.06 &
\end{tabular}

$A D F$, acid detergent fiber; NDF, neutral detergent fiber.

iv) corn-SBM based diet +wheat 45\% (W45), and v) corn-SBM based diet+wheat $60 \%$ (W60). The wheat (soft red winter) which used in this experiment was imported from Australia. All nutrients met or exceeded the requirement of NRC [3] and experimental diet formulas and chemical compositions are presented in Table $2,3,4$, and 5 .

\section{Blood sampling and analyses}

In each treatment, 6 pigs of near average BW were bled through the anterior vena cava to measure glucose, total cholesterol, creatinine, blood urea nitrogen (BUN), and total protein. Blood sampling was done on the initial day and at the end of each phase. The blood samples were collected in a disposable culture tube and centrifuged for $15 \mathrm{~min}$ by $3,000 \mathrm{rpm}$ at $4^{\circ} \mathrm{C}$ (Eppendorf centrifuge 5810R, Hamburg, Germany). The sera were carefully transferred to $1.5-\mathrm{mL}$ plastic tubes and stored at $-20^{\circ} \mathrm{C}$ for later analysis. The total BUN concentration was analyzed using a blood analyzer (Ciba-Corning model, Express Plus, Ciba Corning Diagnostics Co., Cambridge, MA, USA). The creatinine and total protein concentration were measured by kinetic colorimetry assay using a blood analyzer (Modular Analytics, PE, Roche, Germany).

\section{Nutrient digestibility}

A digestibility trial was conducted in a completely randomized design with three replicates to evaluate the nutrient digestibility and nitrogen retention. An experimental diet of finishing phase 1 was provided to each treatment animal. A total of 15 crossbred growing barrows, averaging $71.16 \pm 3.50 \mathrm{~kg} \mathrm{BW}$, were individually allotted to each treatment and housed in metabolic crates. A total 
Table 2. Formula and chemical compositions of the experimental diets in growing phase 1 (Growing 1)

\begin{tabular}{|c|c|c|c|c|c|}
\hline \multirow{2}{*}{ Items } & \multicolumn{5}{|c|}{ Treatments $^{1)}$} \\
\hline & CON & W15 & W30 & W45 & W60 \\
\hline \multicolumn{6}{|l|}{ Ingredients (\%) } \\
\hline Corn & 62.18 & 48.50 & 34.82 & 21.11 & 7.45 \\
\hline SBM $(45 \%$ CP) & 28.08 & 26.31 & 24.55 & 22.80 & 21.02 \\
\hline Wheat & 0.00 & 15.00 & 30.00 & 45.00 & 60.00 \\
\hline Wheat bran & 3.00 & 3.00 & 3.00 & 3.00 & 3.00 \\
\hline Palm kernel meal & 3.00 & 3.00 & 3.00 & 3.00 & 3.00 \\
\hline Tallow & 1.44 & 1.86 & 2.28 & 2.71 & 3.13 \\
\hline MDCP & 0.83 & 0.76 & 0.69 & 0.63 & 0.56 \\
\hline Limestone & 0.87 & 0.92 & 0.96 & 1.00 & 1.04 \\
\hline L-lysine-HCI (78\%) & 0.00 & 0.04 & 0.09 & 0.13 & 0.18 \\
\hline DL-methionine (80\%) & 0.00 & 0.01 & 0.01 & 0.02 & 0.02 \\
\hline Vit. $M i^{2)}$ & 0.10 & 0.10 & 0.10 & 0.10 & 0.10 \\
\hline Min. $\mathrm{Mix}^{3)}$ & 0.10 & 0.10 & 0.10 & 0.10 & 0.10 \\
\hline Salt & 0.30 & 0.30 & 0.30 & 0.30 & 0.30 \\
\hline Phytase & 0.10 & 0.10 & 0.10 & 0.10 & 0.10 \\
\hline Total & 100.00 & 100.00 & 100.00 & 100.00 & 100.00 \\
\hline \multicolumn{6}{|l|}{ Chemical composition } \\
\hline ME (kcal/kg) & 3,265 & 3,265 & 3,265 & 3,265 & 3,265 \\
\hline Crude protein $(\%)^{5)}$ & 19.58 & 19.95 & 20.24 & 19.78 & 20.21 \\
\hline Crude fat $(\%)^{5)}$ & 4.68 & 5.19 & 5.15 & 5.98 & 6.03 \\
\hline Crude ash $(\%)^{5)}$ & 9.45 & 9.86 & 10.31 & 9.52 & 9.15 \\
\hline Lysine $(\%)^{4)}$ & 0.95 & 0.95 & 0.95 & 0.95 & 0.95 \\
\hline Methionine $(\%)^{4)}$ & 0.28 & 0.28 & 0.28 & 0.28 & 0.28 \\
\hline $\mathrm{Ca}(\%)^{4)}$ & 0.60 & 0.60 & 0.60 & 0.60 & 0.60 \\
\hline Total P $(\%)^{4)}$ & 0.50 & 0.50 & 0.50 & 0.50 & 0.50 \\
\hline
\end{tabular}

SBM, soybean meal; $C P$, crude protein; MDCP, mono-dicalcium phosphate; ME, metabolizable energy.

1) CON, wheat $0 \%$; W15, wheat $15 \%$; W30, wheat $30 \%$; W45, wheat $45 \%$; W60, wheat $60 \%$.

2) Provided the following quantities of vitamins per $\mathrm{kg}$ of complete diet: vitamin $\mathrm{A}, 8,020$ $\mathrm{IU}$; vitamin C, $100 \mathrm{IU}$; vitamin $\mathrm{D}_{3}, 1,604 \mathrm{IU}$; vitamin $\mathrm{K}_{3}, 1.6 \mathrm{mg}$; rivoflavin, $1.6 \mathrm{mg}$; calcium pantothenic acid, $6 \mathrm{mg}$; niacin, 10 mg; biotin, $40 \mu \mathrm{g}$; vitamin $\mathrm{B}_{12}, 10 \mu \mathrm{g}$.

${ }^{3)}$ Provided the following quantities of minerals per $\mathrm{kg}$ of complete diet: $\mathrm{Fe}, 187 \mathrm{mg} ; \mathrm{Cu}$, 88 mg; Mn, 167 mg; I, 1 mg; Se, 1 mg; Zn, 103 mg.

4) Calculated value.

${ }^{5)}$ Analyzed value.

collection method was utilized for the apparent digestibility. After 7 days of adaptation period, pigs were subjected to 5 days collection and $0.4 \%$ of ferric oxide and chromium oxide were used as initial and end marker respectively. During the experimental period, water was provided ad libitum and all pigs were fed a daily level of 2.7 times the estimated maintenance requirement for energy (i.e., $106 \mathrm{kcal}$ of metabolizable energy [ME] per kg of $\mathrm{BW}^{0.75}$ ) [9]. Excreta and urine were collected daily and stored at $-20^{\circ} \mathrm{C}$ for later analysis.

\section{Carcass traits}

At the end of the experiment, 4 pigs from each treatment group were selected and slaughtered for the carcass analysis. Pork samples were collected from nearby the 10th rib on the right side of the carcass. Because of the chilling procedure, 30 minutes after slaughter was regarded as the initial time. The $\mathrm{pH}$, meat, and back
Table 3. Formula and chemical compositions of the experimental diets in growing phase 2 (Growing 2)

\begin{tabular}{|c|c|c|c|c|c|}
\hline \multirow{2}{*}{ Items } & \multicolumn{5}{|c|}{ Treatments $^{1)}$} \\
\hline & CON & W15 & W30 & W45 & W60 \\
\hline \multicolumn{6}{|l|}{ Ingredients (\%) } \\
\hline Corn & 66.94 & 53.28 & 39.57 & 25.90 & 12.18 \\
\hline SBM (45\% CP) & 23.68 & 21.90 & 20.16 & 18.37 & 16.64 \\
\hline Wheat & 0.00 & 15.00 & 30.00 & 45.00 & 60.00 \\
\hline Wheat bran & 3.00 & 3.00 & 3.00 & 3.00 & 3.00 \\
\hline Palm kernel meal & 3.00 & 3.00 & 3.00 & 3.00 & 3.00 \\
\hline Tallow & 1.25 & 1.66 & 2.09 & 2.51 & 2.94 \\
\hline $\mathrm{MDCP}$ & 0.75 & 0.68 & 0.61 & 0.54 & 0.47 \\
\hline Limestone & 0.78 & 0.82 & 0.87 & 0.92 & 0.97 \\
\hline L-lysine-HCl (78\%) & 0.00 & 0.05 & 0.09 & 0.14 & 0.18 \\
\hline DL-methionine (80\%) & 0.00 & 0.01 & 0.01 & 0.02 & 0.02 \\
\hline Vit. $\mathrm{Mix}^{2)}$ & 0.10 & 0.10 & 0.10 & 0.10 & 0.10 \\
\hline Min. $\mathrm{Mix}^{3)}$ & 0.10 & 0.10 & 0.10 & 0.10 & 0.10 \\
\hline Salt & 0.30 & 0.30 & 0.30 & 0.30 & 0.30 \\
\hline Phytase & 0.10 & 0.10 & 0.10 & 0.10 & 0.10 \\
\hline Total & 100.00 & 100.00 & 100.00 & 100.00 & 100.00 \\
\hline \multicolumn{6}{|l|}{ Chemical composition } \\
\hline $\mathrm{ME}(\mathrm{kcal} / \mathrm{kg})^{4)}$ & 3,265 & 3,265 & 3,265 & 3,265 & 3,265 \\
\hline Crude protein $(\%)^{5)}$ & 16.61 & 17.03 & 15.39 & 15.83 & 15.56 \\
\hline Crude fat $(\%)^{5)}$ & 4.81 & 5.30 & 5.21 & 5.38 & 5.44 \\
\hline Crude ash $(\%)^{5)}$ & 4.79 & 4.46 & 3.85 & 4.03 & 4.25 \\
\hline Lysine $(\%)^{4)}$ & 0.83 & 0.83 & 0.83 & 0.83 & 0.83 \\
\hline Methionine $(\%)^{4)}$ & 0.26 & 0.26 & 0.26 & 0.26 & 0.26 \\
\hline $\mathrm{Ca}(\%)^{4)}$ & 0.54 & 0.54 & 0.54 & 0.54 & 0.54 \\
\hline Total P $(\%)^{4)}$ & 0.47 & 0.47 & 0.47 & 0.47 & 0.47 \\
\hline
\end{tabular}

SBM, soybean meal; CP, crude protein; MDCP, mono-dicalcium phosphate; ME, metabolizable energy.

1) CON, wheat $0 \%$; W15, wheat $15 \%$; W30, wheat $30 \%$; W45, wheat $45 \%$; W60, wheat $60 \%$.

2) Provided the following quantities of vitamins per $\mathrm{kg}$ of complete diet: vitamin $\mathrm{A}, 8,020$ $\mathrm{IU}$; vitamin C, $100 \mathrm{IU}$; vitamin $\mathrm{D}_{3}, 1,604 \mathrm{IU}$; vitamin $\mathrm{K}_{3}, 1.6 \mathrm{mg}$; rivoflavin, $1.6 \mathrm{mg}$; calcium pantothenic acid, $6 \mathrm{mg}$; niacin, $10 \mathrm{mg}$; biotin, $40 \mu \mathrm{g}$; vitamin $\mathrm{B}_{12}, 10 \mu \mathrm{g}$.

${ }^{3)}$ Provided the following quantities of minerals per $\mathrm{kg}$ of complete diet: $\mathrm{Fe}, 187 \mathrm{mg}$; $\mathrm{Cu}$, 88 mg; Mn, 167 mg; l, 1 mg; Se, 1mg; Zn, 103 mg.

4) Calculated value.

${ }^{5)}$ Analyzed value.

fat color of the longissimus muscle (LM) were measured at 24 hours after slaughter. The $\mathrm{pH}$ was measured using a $\mathrm{pH}$ meter (Model 720, Thermo Orion, Fullerton, CA, USA). Pork and back fat color were determined by Commission Internationale de l'Eclairage (CIE) color $\mathrm{L}^{*}, \mathrm{a}^{\star}$, and $\mathrm{b}^{*}$ values using a CR-300 (Minolta Camera Co., Osaka, Japan). Chemical analysis of the pork samples was conducted using the method of AOAC [10].

\section{Pork quality}

The water-holding capacity (WHC) of the pork was measured by centrifuge. Three LM samples were ground and placed in a filter tube, then heated in a water bath at $80^{\circ} \mathrm{C}$ for $20 \mathrm{~min}$, and centrifuged for $10 \mathrm{~min}$ at $2,000 \mathrm{rpm}$ at $10^{\circ} \mathrm{C}$ (Eppendorf centrifuge 5810R, Germany). To calculate the cooking loss, the LM samples were packed in a polyethylene bag, heated in a water bath until the core temperature reached $72^{\circ} \mathrm{C}$, and weighed before and 
Table 4. Formula and chemical compositions of the experimental diets in finishing phase 1 (Finishing 1)

\begin{tabular}{|c|c|c|c|c|c|}
\hline \multirow{2}{*}{ Items } & \multicolumn{5}{|c|}{ Treatments $^{1)}$} \\
\hline & CON & W15 & W30 & W45 & W60 \\
\hline \multicolumn{6}{|l|}{ Ingredients (\%) } \\
\hline Corn & 69.24 & 55.59 & 41.87 & 28.19 & 14.52 \\
\hline SBM (45\% CP) & 21.60 & 19.86 & 18.08 & 16.33 & 14.58 \\
\hline Wheat & 0.00 & 15.00 & 30.00 & 45.00 & 60.00 \\
\hline Wheat bran & 3.00 & 3.00 & 3.00 & 3.00 & 3.00 \\
\hline Palm kernel meal & 3.00 & 3.00 & 3.00 & 3.00 & 3.00 \\
\hline Tallow & 1.14 & 1.54 & 1.98 & 2.40 & 2.81 \\
\hline MDCP & 0.68 & 0.60 & 0.53 & 0.47 & 0.40 \\
\hline Limestone & 0.74 & 0.77 & 0.84 & 0.87 & 0.90 \\
\hline L-lysine-HCI (78\%) & 0.00 & 0.04 & 0.09 & 0.13 & 0.17 \\
\hline DL-methionine (80\%) & 0.00 & 0.00 & 0.01 & 0.01 & 0.02 \\
\hline Vit. Mix & 0.10 & 0.10 & 0.10 & 0.10 & 0.10 \\
\hline Min. $\mathrm{Mix}^{3)}$ & 0.10 & 0.10 & 0.10 & 0.10 & 0.10 \\
\hline Salt & 0.30 & 0.30 & 0.30 & 0.30 & 0.30 \\
\hline Phytase & 0.10 & 0.10 & 0.10 & 0.10 & 0.10 \\
\hline Total & 100.00 & 100.00 & 100.00 & 100.00 & 100.00 \\
\hline \multicolumn{6}{|l|}{ Chemical composition } \\
\hline ME $(\mathrm{kcal} / \mathrm{kg})^{4)}$ & 3,265 & 3,265 & 3,265 & 3,265 & 3,265 \\
\hline Crude protein $(\%)^{5)}$ & 16.17 & 15.99 & 15.28 & 14.77 & 14.94 \\
\hline Crude fat $(\%)^{5)}$ & 6.78 & 5.45 & 4.88 & 5.38 & 5.01 \\
\hline Crude ash $(\%)^{5)}$ & 4.44 & 4.22 & 3.56 & 3.74 & 3.94 \\
\hline Lysine $(\%)^{4)}$ & 0.78 & 0.78 & 0.78 & 0.78 & 0.78 \\
\hline Methionine $(\%)^{4)}$ & 0.25 & 0.25 & 0.25 & 0.25 & 0.25 \\
\hline $\mathrm{Ca}(\%)^{4)}$ & 0.50 & 0.50 & 0.50 & 0.50 & 0.50 \\
\hline Total P $(\%)^{4)}$ & 0.45 & 0.45 & 0.45 & 0.45 & 0.45 \\
\hline
\end{tabular}

SBM, soybean meal; CP, crude protein; ; MDCP, mono-dicalcium phosphate; ME, metabolizable energy.

1) CON, wheat $0 \%$; W15, wheat $15 \%$; W30, wheat $30 \%$; W45, wheat $45 \%$; W60, wheat $60 \%$.

2) Provided the following quantities of vitamins per $\mathrm{kg}$ of complete diet: vitamin $\mathrm{A}, 8,020$ IU; vitamin C, $100 \mathrm{IU}$; vitamin $\mathrm{D}_{3}, 1,604 \mathrm{IU}$; vitamin $\mathrm{K}_{3}, 1.6 \mathrm{mg}$; riboflavin, $1.6 \mathrm{mg}$; calcium pantothenic acid, $6 \mathrm{mg}$; niacin, 10 mg; biotin, $40 \mu \mathrm{g}$; vitamin $\mathrm{B}_{12}, 10 \mu \mathrm{g}$

${ }^{3)}$ Provided the following quantities of minerals per $\mathrm{kg}$ of complete diet: $\mathrm{Fe}, 187 \mathrm{mg} ; \mathrm{Cu}$, $88 \mathrm{mg} ; \mathrm{Mn}, 167 \mathrm{mg} ; \mathrm{l}, 1 \mathrm{mg} ; \mathrm{Se}, 1 \mathrm{mg} ; \mathrm{Zn}, 103 \mathrm{mg}$.

4) Calculated value.

${ }^{5)}$ Analyzed value.

after heating. After heating, the samples were cored $(0.5 \times 1.0 \times 1.5$ $\mathrm{cm}$ ) parallel to the muscle fiber and the cores were used to measure the shear force using a salter (Warner Barzler Shear, Norwood, MA, USA). The amino acid content of the loin meat was determined by ion-exchange chromatography (Amino Acid Analyzer L-8900, Hitachi, Tokyo, Japan) with post-column derivatization with ninhydrin. Performic acid was used in oxidizing the amino acids and was neutralized with sodium citrate dihydrate and then hydrolyzed with $6 \mathrm{~N} \mathrm{HCl}$ for 22 hours at $110^{\circ} \mathrm{C}$ to be liberated from the protein. Amino acids were quantified with the internal standard method (amino acid mixture standard solution Type H, Wako Chemical, Osaka, Japan; L-cysteic acid, Tokyo Chemical Industry, Tokyo, Japan; DL-methionine sulfone, Sigma, St. Louis, MO, USA) by measuring the absorption of the reaction products with ninhydrin at $570 \mathrm{~nm}$.
Table 5. Formula and chemical compositions of the experimental diets in finishing phase 2 (Finishing 2)

\begin{tabular}{|c|c|c|c|c|c|}
\hline \multirow{2}{*}{ Items } & \multicolumn{5}{|c|}{ Treatments $^{1)}$} \\
\hline & CON & W15 & W30 & W45 & W60 \\
\hline \multicolumn{6}{|l|}{ Ingredients (\%) } \\
\hline Corn & 75.54 & 61.91 & 48.19 & 34.52 & 20.82 \\
\hline SBM (45\% CP) & 15.69 & 13.90 & 12.15 & 10.38 & 8.65 \\
\hline Wheat & 0.00 & 15.00 & 30.00 & 45.00 & 60.00 \\
\hline Wheat bran & 3.00 & 3.00 & 3.00 & 3.00 & 3.00 \\
\hline Palm kernel meal & 3.00 & 3.00 & 3.00 & 3.00 & 3.00 \\
\hline Tallow & 0.92 & 1.33 & 1.76 & 2.18 & 2.60 \\
\hline $\mathrm{MDCP}$ & 0.51 & 0.46 & 0.40 & 0.32 & 0.24 \\
\hline Limestone & 0.74 & 0.75 & 0.80 & 0.85 & 0.90 \\
\hline L-lysine-HCl (78\%) & 0.00 & 0.05 & 0.10 & 0.14 & 0.18 \\
\hline DL-methionine (80\%) & 0.00 & 0.00 & 0.00 & 0.01 & 0.01 \\
\hline Vit. $M i x^{2)}$ & 0.10 & 0.10 & 0.10 & 0.10 & 0.10 \\
\hline Min. $\mathrm{Mix}^{3)}$ & 0.10 & 0.10 & 0.10 & 0.10 & 0.10 \\
\hline Salt & 0.30 & 0.30 & 0.30 & 0.30 & 0.30 \\
\hline Phytase & 0.10 & 0.10 & 0.10 & 0.10 & 0.10 \\
\hline Total & 100.00 & 100.00 & 100.00 & 100.00 & 100.00 \\
\hline \multicolumn{6}{|l|}{ Chemical composition } \\
\hline $\mathrm{ME}(\mathrm{kcal} / \mathrm{kg})^{4)}$ & 3,265 & 3,265 & 3,265 & 3,265 & 3,265 \\
\hline Crude protein $(\%)^{5)}$ & 14.60 & 14.42 & 13.47 & 14.07 & 13.64 \\
\hline Crude fat $(\%)^{5)}$ & 5.04 & 3.56 & 3.88 & 4.02 & 4.46 \\
\hline Crude ash $(\%)^{5)}$ & 4.45 & 3.46 & 3.26 & 3.23 & 3.51 \\
\hline Lysine $(\%)^{4)}$ & 0.62 & 0.62 & 0.62 & 0.62 & 0.62 \\
\hline Methionine $(\%)^{4)}$ & 0.23 & 0.23 & 0.23 & 0.23 & 0.23 \\
\hline $\mathrm{Ca}(\%)^{4)}$ & 0.45 & 0.45 & 0.45 & 0.45 & 0.45 \\
\hline Total P $(\%)^{4)}$ & 0.40 & 0.40 & 0.40 & 0.40 & 0.40 \\
\hline
\end{tabular}

SBM, soybean meal; CP, crude protein; MDCP, mono-dicalcium phosphate; ME, metabolizable energy.

1) CON, wheat $0 \%$; W15, wheat $15 \%$; W30, wheat $30 \%$; W45, wheat $45 \%$; W60, wheat $60 \%$.

2) Provided the following quantities of vitamins per $\mathrm{kg}$ of complete diet: vitamin $\mathrm{A}, 8,020$ $\mathrm{IU}$; vitamin C, $100 \mathrm{IU}$; vitamin $\mathrm{D}_{3}, 1,604 \mathrm{IU}$; vitamin $\mathrm{K}_{3}, 1.6 \mathrm{mg}$; rivoflavin, $1.6 \mathrm{mg}$; calcium pantothenic acid, $6 \mathrm{mg}$; niacin, $10 \mathrm{mg}$; biotin, $40 \mu \mathrm{g}$; vitamin $\mathrm{B}_{12}, 10 \mu \mathrm{g}$.

${ }^{3)}$ Provided the following quantities of minerals per $\mathrm{kg}$ of complete diet: $\mathrm{Fe}, 187 \mathrm{mg}$; $\mathrm{Cu}$, 88 mg; Mn, 167 mg; l, 1 mg; Se, 1mg; Zn, 103 mg.

4) Calculated value.

${ }^{5)}$ Analyzed value.

\section{Chemical analyses}

Diets were ground by a Cyclotec 1093 Sample Mill (Foss Tecator, Hillerod, Denmark) and the ground diets were then analyzed. All analyses were performed in duplicate samples and repeated if the results from the duplicate samples varied more than 5\% from the mean. The dry matter of the diet samples were determined by oven drying at $135^{\circ} \mathrm{C}$ for 2 hours (method 930.15) [10]. Aspartic acid was used as a calibration standard, $\mathrm{CP}$ was calculated as $\mathrm{N} \times 6.25$, and the diets were also analyzed for ash (method 942.05) [10]. The collected excreta were pooled and dried in an air-forced drying oven at $60^{\circ} \mathrm{C}$ for 72 hours, and then ground into 1-mm particles in a Wiley mill for chemical analysis, including moisture, protein, fat, and ash contents [10]. Total urine was collected daily in a plastic container containing $50 \mathrm{~mL}$ of $4 \mathrm{~N} \mathrm{H}_{2} \mathrm{SO}_{4}$ and then frozen during the 5-day collection period for nitrogen retention analyses. 
Estimation of amino acid content in wheat and corn was carried out with AccQ-Tag regent kits (Waters, Milford, MA, USA). Performic acid was used in oxidizing amino acids and neutralized with sodium citrate dihydrate, and then hydrolyzed with $6 \mathrm{~N} \mathrm{HCl}$ for $24 \mathrm{~h}$ at $110^{\circ} \mathrm{C}$ to liberate it from the protein. Amino acids were analyzed on high performance liquid chromatography (Waters 486, USA). All separations were generated on NOVA-Pak C18 $(4 \mu \mathrm{m})$ column (Waters, USA) with temperature controlled at $37^{\circ} \mathrm{C}$ and operated with flow rate of $1 \mathrm{~mL} / \mathrm{min}$.

\section{Statistical analyses}

Statistical analysis was determined by least squares mean comparisons using a general linear model procedure in SAS (SAS Institute Inc., Cary, NC, USA). Orthogonal polynomial contrasts were performed to analyze the linear or quadratic effects of increasing wheat levels in the diet. Each pen was considered an experimental unit in measuring growth performance and an individual pig was used as a unit for data on blood profile, pork quality and carcass traits. The significance for treatment effects was reported at $\mathrm{p} \leq 0.05$, with a trend between $\mathrm{p}>0.05$ and $\mathrm{p} \leq 0.10$.

\section{RESULTS AND DISCUSSION}

\section{Chemical composition of corn and wheat}

Wheat used in this experiment contained higher CP $(11.25 \%)$ and essential amino acids (Arg: $0.50 \%$, His: $0.25 \%$, Ile: $0.36 \%$, Leu: $0.72 \%$, Lys: $0.28 \%$, Met $0.17 \%$, Phe: $0.51 \%$, Thr: $0.34 \%$, Val: $0.43 \%$ ) except for the Leu $(0.72 \%)$. In fiber content, wheat has higher $\mathrm{ADF}(3.60 \%)$ and $\mathrm{NDF}(11.66 \%)$ content than corn.

\section{Growth performance}

The effect of wheat supplementation on growth performance is shown in Table 6. During the entire feeding trial, there were no significant differences in $\mathrm{BW}, \mathrm{ADG}$, and $\mathrm{ADFI}$ among treatments. As the dietary wheat supplementation levels increased, the G:F ratio tended to increase (linear, $\mathrm{p}=0.08$ ). As the pigs were fed higher wheat treatment diets, the G:F ratio tended to increase during weeks 7 to 11 (quadratic, $p=0.06$ ). This result implies that

Table 6. Effect of wheat supplementation levels on growth performance in growing-finishing pigs"

\begin{tabular}{|c|c|c|c|c|c|c|c|c|}
\hline \multirow{2}{*}{ Criteria } & \multicolumn{5}{|c|}{ Treatments $^{2)}$} & \multirow{2}{*}{ SEM } & \multicolumn{2}{|c|}{$p$-value } \\
\hline & CON & W15 & W30 & W45 & W60 & & Lin. & Quad. \\
\hline \multicolumn{9}{|l|}{ Body weight (kg) } \\
\hline Initial & 27.75 & 27.75 & 27.75 & 27.75 & 27.75 & - & - & - \\
\hline $3 w k$ & 40.44 & 42.16 & 39.00 & 40.41 & 41.78 & 1.320 & 0.55 & 0.27 \\
\hline $6 w k$ & 55.51 & 56.08 & 53.94 & 54.38 & 56.87 & 2.014 & 0.89 & 0.43 \\
\hline 9 wk & 75.50 & 78.30 & 76.71 & 76.57 & 79.93 & 2.461 & 0.53 & 0.93 \\
\hline $11 w k$ & 91.70 & 92.09 & 91.13 & 92.19 & 95.81 & 2.898 & 1.00 & 0.95 \\
\hline \multicolumn{9}{|l|}{$A D G(g)$} \\
\hline 1 to $3 w k$ & 623 & 686 & 543 & 603 & 668 & 39.4 & 0.60 & 0.16 \\
\hline 4 to $6 w k$ & 718 & 663 & 711 & 685 & 718 & 28.0 & 0.60 & 0.97 \\
\hline 7 to $9 w k$ & 952 & 1,058 & 1,084 & 1,057 & 1,098 & 27.6 & 0.17 & 0.24 \\
\hline 10 to $11 w k$ & 996 & 985 & 1,030 & 1,116 & 1,134 & 25.6 & 0.65 & 0.18 \\
\hline 1 to 6 wk & 657 & 674 & 627 & 634 & 693 & 31.4 & 0.83 & 0.46 \\
\hline 7 to $11 w k$ & 963 & 1,029 & 1,019 & 1,080 & 1,113 & 24.8 & 0.59 & 0.35 \\
\hline 1 to 11 wk & 758 & 766 & 756 & 767 & 810 & 21.3 & 0.95 & 1.00 \\
\hline \multicolumn{9}{|l|}{$\operatorname{ADFI}(g)$} \\
\hline 1 to $3 w k$ & 1,452 & 1,523 & 1,361 & 1,525 & 1,549 & 79.3 & 0.89 & 0.59 \\
\hline 4 to 6 wk & 1,809 & 1,695 & 1,656 & 1,777 & 1,963 & 80.2 & 0.34 & 0.74 \\
\hline 7 to $9 w k$ & 2,799 & 2,755 & 2,801 & 2,726 & 2,866 & 96.7 & 0.94 & 0.94 \\
\hline 10 to $11 w k$ & 2,931 & 2,783 & 2,726 & 2,891 & 3,026 & 54.5 & 0.24 & 0.66 \\
\hline 1 to 6 wk & 1,630 & 1,609 & 1,508 & 1,651 & 1,756 & 77.0 & 0.58 & 0.64 \\
\hline 7 to $11 w k$ & 2,936 & 2,845 & 2,849 & 2,874 & 3,016 & 75.4 & 0.65 & 0.84 \\
\hline 1 to $11 w k$ & 2,195 & 2,143 & 2,091 & 2,179 & 2,299 & 72.1 & 0.59 & 0.73 \\
\hline \multicolumn{9}{|l|}{ G:F ratio } \\
\hline 1 to 3 wk & 0.421 & 0.448 & 0.390 & 0.399 & 0.435 & 0.0115 & 0.47 & 0.09 \\
\hline 4 to 6 wk & 0.406 & 0.391 & 0.436 & 0.373 & 0.368 & 0.0110 & 0.88 & 0.82 \\
\hline 7 to $9 w k$ & 0.345 & 0.385 & 0.397 & 0.392 & 0.384 & 0.0092 & 0.08 & 0.06 \\
\hline 10 to $11 w k$ & 0.340 & 0.357 & 0.379 & 0.387 & 0.376 & 0.0086 & 0.61 & 0.08 \\
\hline 1 to 6 wk & 0.404 & 0.417 & 0.417 & 0.384 & 0.396 & 0.0070 & 0.32 & 0.53 \\
\hline 7 to 11 wk & 0.329 & 0.363 & 0.360 & 0.378 & 0.370 & 0.0064 & 0.13 & 0.06 \\
\hline 1 to 11 wk & 0.348 & 0.357 & 0.365 & 0.354 & 0.354 & 0.0053 & 0.42 & 0.53 \\
\hline
\end{tabular}

SEM, standard error of mean; Lin, linear; Quad, quadratic; ADG, average daily gain; ADFl, average daily feed intake; G:F ratio, gain-to-feed.

1) A total of 120 crossbred pigs was fed from average initial body $27.75 \pm 6.391 \mathrm{~kg}$ and the average final body weight was $92.58 \mathrm{~kg}$.

2) CON, wheat $0 \%$; W15, wheat $15 \%$; W 30 , wheat $30 \%$; W45, wheat $45 \%$; W60, wheat $60 \%$. 
wheat can improve finishing pig's feed efficiency when it was supplemented in swine diet.

Supplementation with wheat levels in swine diet has been studied for many years. Seerley et al [11] reported that wheat could replace a corn-SBM-based diet by $81 \%$ during the growing period and $86 \%$ during the finishing period. In this study, wheat supplementation did not show any negative influence on growth performance in a growing-finishing pig.

Pigs fed a wheat-supplemented diet grew similar in size to pigs fed a corn-SBM diet $[5,11]$. There was no significant difference in the ADG between corn-based and wheat-based diets. The wheat supplementation level of this experiment ranged from $20 \%$ to $85.98 \%$ in the diet of growing-finishing pigs. Thus, the growth of pigs that were fed a wheat-supplemented diet was expected to be similar to that of pigs fed a corn-SBM diet. Wheat could replace corn in diets for growing-finishing pigs, if diets met the amino acid and protein requirements [6]. This result demonstrated that $60 \%$ of wheat supplementation did not have a detrimental effect on the growth of the growing-finishing pigs.

Seerly et al [11] and Van Lunen and Schulze [12] reported that pigs fed a wheat-based diet had a significantly higher ADFI than those fed a corn-based diet. However, some researchers reported that there was no significant difference between corn and wheat diets [13]. Wheat had a high palatability in previous experiments on weaning pigs [14], but there was no significant difference in the ADFI among the treatments in the present experiment. This result demonstrated that palatability and feed intake were not affected in the growing-finishing pigs.

Van Lunen and Schulze [12] reported that $60 \%$ of wheat inclusion resulted in a higher feed consumption but this was not translated into ADG resulting in a slightly but significantly lower G:F ratio. However, they supplemented xylanase instead of phytase. Phytase is one reason why the G:F ratio improved in wheat treatments. Corn has a higher phytic acid content than wheat and phosphorus digestibility is lower than wheat [3]. The improvement in the G:F ratio when including phytase in the wheat treatments could also be explained by phytase acting on other nutrients that are bound to the phytate form, thus releasing more energy and protein.

When comparing the particle size of the feed ingredients that are used in swine diet, wheat is finer than corn. In this study, pigs fed wheat had a higher G:F ratio than pigs fed corn-SBM treatment during the finishing period. These results were in agreement with the result of Mavromichalis et al [15] who demonstrated that feeding wheat with a fine particle size improved the G:F ratio in finishing pigs. However, regardless of the particle size of wheatbased diets, corn-SBM diets had a higher G:F ratio during the finishing period but a similar G:F ratio during the growing period [11].

The present study showed that the performance of finishing pigs could be improved by feeding them wheat rather than corn. Finishing pigs fed the wheat-based diet showed a better G:F ratio by $9 \%$ to $14 \%$. Meanwhile, this study suggested that a wheat-based diet is recommended in finishing period.

\section{Nutrient digestibility}

The effect of wheat supplementation levels on nutrient digestibility is presented in Table 7. In this trial, wheat-supplemented treatments did not produce a beneficial effect $(\mathrm{p}>0.05)$, but pig feds the wheat-based diet tended to have lower nutrient digestibility of ash and fat than those fed the corn-SBM diet $(\mathrm{p}<0.08)$. There were some differences in nitrogen intake among treatments (respectively $49.18 \%, 49.02 \%, 50.38 \%, 45.46 \%$, and $46.74 \%$ ) due to the different $\mathrm{CP}$ concentration between corn and wheat. However, there was no significant differences among them $(\mathrm{p}>0.05)$. Nitrogen retention also was not affected by wheat supplementation levels $(\mathrm{p}>0.05)$.

There are few studies that did experiments on digestibility of

Table 7. Effect of wheat supplementation levels on nutrient digestibility in growing-finishing pigs ${ }^{11}$

\begin{tabular}{|c|c|c|c|c|c|c|c|c|}
\hline \multirow{2}{*}{ Criteria } & \multicolumn{5}{|c|}{ Treatments $^{2)}$} & \multirow{2}{*}{ SEM } & \multicolumn{2}{|c|}{$p$-value } \\
\hline & CON & W15 & W30 & W45 & W60 & & Lin. & Quad. \\
\hline \multicolumn{9}{|c|}{ Nutrient digestibility (\%) } \\
\hline Dry matter & 92.00 & 91.22 & 91.23 & 90.51 & 92.30 & 0.635 & 0.76 & 0.53 \\
\hline Crude protein & 86.64 & 85.37 & 84.96 & 82.60 & 86.11 & 1.147 & 0.88 & 0.31 \\
\hline Crude ash & 64.12 & 56.47 & 47.53 & 40.55 & 56.47 & 4.193 & 0.56 & 0.06 \\
\hline Crude fat & 90.69 & 87.85 & 85.25 & 86.01 & 86.53 & 1.104 & 0.21 & 0.07 \\
\hline \multicolumn{9}{|l|}{ N-retention (g/d) } \\
\hline $\mathrm{N}$-intake & 49.18 & 49.02 & 50.38 & 45.46 & 46.74 & 0.804 & 0.59 & 0.53 \\
\hline $\mathrm{N}$-feces & 6.54 & 7.12 & 7.84 & 7.86 & 6.50 & 0.605 & 0.76 & 0.43 \\
\hline N-urine & 13.55 & 17.09 & 12.31 & 15.87 & 14.57 & 0.823 & 0.27 & 0.59 \\
\hline N-retention ${ }^{3)}$ & 29.09 & 24.81 & 29.28 & 21.74 & 25.67 & 1.280 & 0.58 & 0.51 \\
\hline $\mathrm{N}$-digest & 59.03 & 50.54 & 58.47 & 47.59 & 54.86 & 2.331 & 0.42 & 0.65 \\
\hline
\end{tabular}

SEM, standard error of mean; Lin, linear; Quad, quadratic.

${ }^{1)} \mathrm{A}$ total of 15 crossbred pigs were fed from an average initial body weight $71.16 \pm 3.50 \mathrm{~kg}$.

2) CON, wheat 0\%; W15, wheat 15\%; W30, wheat 30\%; W45, wheat 45\%; W60, wheat $60 \%$.

${ }^{3)} \mathrm{N}$ retention $=\mathrm{N}$ intake $(\mathrm{g})-$ Fecal $\mathrm{N}(\mathrm{g})$-Urinary $\mathrm{N}(\mathrm{g})$. 
different corn and wheat levels. Some researchers reported higher digestibility of $\mathrm{CP}$ and amino acid [16] but another study reported that there were no differences in nitrogen and dry matter digestibility when compared with that of corn [17]. In this study, there was no improvement of dry matter, $\mathrm{CP}$, and nitrogen digestion. So we could conclude that wheat supplementation did not have a negative effect on them.

Two major enzymes that are supplemented in wheat-based diets are phytase and xylanase. There are many studies that have evaluated the efficiency of the enzymes [18]. There was no significant difference between phytase and a combination of phytase and xylanase in either growth performance or nutrient digestibility [19]. Generally, there was a positive correlation between the G:F ratio and nutrient digestibility in pigs.

Lower digestibility of crude fat and ash could be due to the increased digesta passage rate, which in turn decreased digestion and absorption in the small intestine [20]. The digesta passage rate was affected by the viscous fiber content in the pigs' diet [21]. Wheat contains higher crude fiber [3] and total non-starch polysaccharide [22] than corn. We can conclude that a high fiber content increased the viscosity of the digesta and passage rate, and crude fat and ash digestibility decreased when wheat was supplemented in the pigs' diet. The reason why the wheat-based diet had low digestibility of crude fat also can be explained by the composition of crude fat in the experimental diet during finishing period 1 (CON: 6.78\%, W15: 5.45\%, W30: 4.88\%, W45: 5.38\%, W60: 5.01\%). Wheat-based diets had a slightly lower crude fat content than the corn-SBM diet. Generally, their digestibility was affected by their concentration in the diet [23]. When there was high intact or extracted fat in the diet, there was a higher digestibility of fat [24] and dietary crude fat increased the digestibility of crude fat in pigs [23]. Crude fat digestibility may be increased for this reason.

\section{Blood profiles}

The effect of wheat supplementation levels on blood profiles is presented in Table 8. During the entire experimental period, creatinine and BUN were normal regardless of wheat supplementation and no significant differences were observed among the treatments. However, total protein concentration at 6 weeks tended to decrease as the wheat supplementation level increased (quadratic; $\mathrm{p}=0.08$ ).

Bergsjø et al [25] reported a negative correlation between protein intake and serum total protein concentration. A greater serum total protein level indicated that the protein status improved in pigs [26]. The serum total protein level decreased in growing pigs when the contaminated wheat level increased [27]. Thus, our result was derived from including a high level of wheat, which could contain more toxins than corn. However, the normal serum total protein level range was 5.41 to $6.80 \mathrm{mg} / \mathrm{dL}$ [28]. The high level of wheat did not have a detrimental effect on the serum total protein level.

Normally, the serum BUN concentration can be used as an index of protein and amino acid utilization in pigs [29]. However, the result of this study did not affect the serum BUN concentration and this indicated that there was no difference in excessive amino acid between wheat and corn.

Blood creatinine is widely used to calculate body muscle con-

Table 8. Effect of wheat supplementation levels on blood profiles in growing-finishing pigs ${ }^{1)}$

\begin{tabular}{|c|c|c|c|c|c|c|c|c|}
\hline \multirow{2}{*}{ Criteria } & \multicolumn{5}{|c|}{ Treatments $^{2)}$} & \multirow{2}{*}{ SEM } & \multicolumn{2}{|c|}{$p$-value } \\
\hline & CON & W15 & W30 & W45 & W60 & & Lin. & Quad. \\
\hline \multicolumn{9}{|c|}{ Creatinine $(\mathrm{mg} / \mathrm{dL})$} \\
\hline Initial & -------- & $\ldots$ & 0.7 & - n & -1--- & - & - & - \\
\hline 3 week & 0.70 & 0.78 & 0.93 & 0.64 & 0.79 & 0.047 & 0.27 & 0.69 \\
\hline 6 week & 0.89 & 0.94 & 1.10 & 0.87 & 0.77 & 0.037 & 0.34 & 0.40 \\
\hline 9 week & 0.73 & 0.99 & 1.01 & 0.94 & 0.82 & 0.052 & 0.14 & 0.38 \\
\hline 11 week & 1.00 & 1.03 & 0.94 & 0.99 & 1.06 & 0.039 & 0.93 & 0.57 \\
\hline \multicolumn{9}{|l|}{ BUN (mg/dL) } \\
\hline Initial & 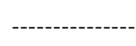 & -1 & --- 8 & -1---- & 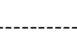 & - & - & - \\
\hline 3 week & 14.8 & 12.5 & 12.3 & 13.4 & 15.4 & 0.52 & 0.13 & 0.51 \\
\hline 6 week & 11.1 & 11.8 & 11.0 & 13.4 & 12.6 & 0.38 & 0.90 & 0.41 \\
\hline 9 week & 13.6 & 14.2 & 12.5 & 14.6 & 13.7 & 0.58 & 0.95 & 0.82 \\
\hline 11 week & 10.8 & 13.5 & 12.2 & 14.3 & 14.1 & 0.64 & 0.36 & 0.46 \\
\hline \multicolumn{9}{|c|}{ Total protein (mg/dL) } \\
\hline Initial & ----- & 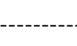 & ------ 6 & - & --..- & - & - & - \\
\hline 3 week & 6.6 & 6.8 & 6.8 & 6.4 & 6.3 & 0.07 & 0.23 & 0.41 \\
\hline 6 week & 6.8 & 6.9 & 6.6 & 6.4 & 6.1 & 0.09 & 0.70 & 0.08 \\
\hline 9 week & 6.9 & 6.9 & 6.9 & 6.6 & 6.5 & 0.09 & 0.95 & 0.38 \\
\hline 11 week & 6.9 & 6.7 & 6.7 & 6.4 & 6.4 & 0.09 & 0.93 & 0.19 \\
\hline
\end{tabular}

SEM, standard error of mean; Lin, linear; Quad, quadratic; BUN, blood urea nitrogen.

1) Least squares means of 6 observations per treatment.

2) CON, wheat $0 \%$; W15, wheat $15 \%$; W30, wheat $30 \%$; W45, wheat $45 \%$; W60, wheat $60 \%$. 
tent, and blood creatinine concentration has a positive correlation with the total muscles in the body [30]. No difference was detected in this experiment so we can conclude that neither wheat nor corn affected muscle production in growing-finishing pigs.

\section{Carcass traits}

The effect of wheat supplementation levels on carcass traits is presented in Table 9. In this study, we cannot find any significant difference in moisture, CP, and crude fat. However, the crude ash concentration decreased as the wheat supplementation level increased (linear, $\mathrm{p}=0.05$ ).

Any significant difference in physiochemical property was not detected by wheat supplementation levels on cooking loss, shear force, and WHC among treatments.

Numerous studies reported that there was no detrimental effect on pork quality when wheat was used as a feed ingredient [5]. Crude ash was affected by many factors such as the fat content in pork. There are negative correlations between crude fat and ash. However, we did not find an interrelationship between them and only crude ash was decreased. The crude ash content of the diet was lower in the wheat inclusion treatment and control. For this reason, there was low crude ash in pork. The crude ash content indicated an evolutionary tenderness when the ash content increased [31]. A sensory test may be used to find out the relationship between crude ash and tenderness.

There were no differences in physiochemical properties among the treatments in this study. This result was in accordance with that of Carr et al [13], who reported that cooking loss, shear force, and WHC were not affected by feed ingredients especially between corn and wheat.

\section{Pork quality}

Table 10 shows the effect of wheat supplementation levels on meat color (Hunter-value) and $\mathrm{pH}$ of LM. No significant differences were observed in $\mathrm{L}^{*}, \mathrm{a}^{*}$, and $\mathrm{b}^{*}$ values and $\mathrm{pH} 24$ hours after slaughter when the pigs were fed different levels of wheat ( $p>0.05$ ). The effect of wheat supplementation levels on back fat color is shown in Table 11. There was no significant difference in back fat color as the wheat supplementation level increased ( $\mathrm{p}>0.05)$.

There was no negative effect in redness and yellowness of LM by wheat supplementation $[5,13]$. These findings are in accordance with our results. A change in the $\mathrm{pH}$ value would be an important factor that determined the pork quality and had an influence on physicochemical property and shelf life [32]. Generally, $\mathrm{pH}$ represented pale, soft, exudative and dark, firm, dry meat [33]. A corn-SBM diet could make the fat a yellow color because of the presence of carotenes and xanthophylls in them

Table 9. Effect of wheat supplementation levels on pork quality of the longissimus muscle ${ }^{1)}$

\begin{tabular}{|c|c|c|c|c|c|c|c|c|}
\hline \multirow{2}{*}{ Criteria } & \multicolumn{5}{|c|}{ Treatments $^{2)}$} & \multirow{2}{*}{ SEM } & \multicolumn{2}{|c|}{ p-value } \\
\hline & CON & W15 & W30 & W45 & W60 & & Lin. & Quad. \\
\hline \multicolumn{9}{|c|}{ Proximate analysis (\%) } \\
\hline Moisture & 70.01 & 70.16 & 69.08 & 70.02 & 68.39 & 0.146 & 0.88 & 0.34 \\
\hline Crude protein & 24.41 & 24.23 & 24.80 & 24.54 & 24.23 & 0.258 & 0.86 & 0.82 \\
\hline Crude fat & 3.79 & 4.39 & 3.87 & 3.29 & 4.49 & 0.309 & 0.45 & 0.47 \\
\hline Crude ash & 1.64 & 1.46 & 1.47 & 1.43 & 1.43 & 0.024 & 0.05 & 0.10 \\
\hline \multicolumn{9}{|c|}{ Physiochemical property (\%) } \\
\hline Cooking loss (\%) & 65.78 & 65.89 & 64.44 & 64.44 & 65.05 & 0.333 & 0.13 & 0.58 \\
\hline Shear force (kg) & 33.66 & 34.20 & 33.74 & 32.20 & 32.70 & 0.836 & 0.35 & 0.32 \\
\hline WHC & 6.88 & 6.65 & 6.08 & 6.07 & 6.17 & 1.566 & 0.74 & 0.56 \\
\hline
\end{tabular}

SEM, standard error of mean; Lin, linear; Quad, quadratic; WHC, water-holding capacity.

1) Least squares means for 4 pigs per treatment.

2) CON, wheat $0 \%$; W15, wheat $15 \%$; W30, wheat $30 \%$; W45, wheat $45 \%$; W60: wheat $60 \%$.

Table 10. Effect of wheat supplementation levels on pork color and pH after slaughter ${ }^{1)}$

\begin{tabular}{|c|c|c|c|c|c|c|c|c|}
\hline \multirow{2}{*}{ Criteria } & \multicolumn{5}{|c|}{ Treatments $^{2)}$} & \multirow{2}{*}{ SEM } & \multicolumn{2}{|c|}{$p$-value } \\
\hline & CON & W15 & W30 & W45 & W60 & & Lin. & Quad. \\
\hline \multicolumn{9}{|l|}{ Hunter value $e^{3)}$} \\
\hline $\mathrm{L}$ & 50.43 & 48.88 & 49.58 & 49.39 & 49.42 & 0.586 & 0.53 & 0.92 \\
\hline a & 5.27 & 5.49 & 5.24 & 5.87 & 5.69 & 0.236 & 0.99 & 0.76 \\
\hline$b$ & 7.60 & 7.67 & 7.08 & 7.54 & 7.36 & 0.173 & 0.88 & 0.44 \\
\hline pH value after slaughter & 5.63 & 5.64 & 5.55 & 5.57 & 5.57 & 0.020 & 0.97 & 0.16 \\
\hline
\end{tabular}

SEM, standard error of mean; Lin, linear; Quad, quadratic.

${ }^{1)}$ Least squares means for 4 pigs per treatment.

2) CON, wheat $0 \%$; W15, wheat $15 \%$; W30, wheat 30\%; W45, wheat $45 \%$; W60, wheat $60 \%$.

${ }^{3)} \mathrm{L}$, luminance or brightness (varies from black to white); a, red and green component (+a: red, -a: green); b, yellow and blue component (+b: yellow, -a: blue). 
Table 11. Effect of wheat supplementation levels on back fat color after slaughter ${ }^{11}$

\begin{tabular}{|c|c|c|c|c|c|c|c|c|}
\hline \multirow{2}{*}{ Criteria } & \multicolumn{5}{|c|}{ Treatments ${ }^{2)}$} & \multirow{2}{*}{ SEM } & \multicolumn{2}{|c|}{$p$-value } \\
\hline & CON & W15 & W30 & W45 & W60 & & Lin. & Quad. \\
\hline \multicolumn{9}{|c|}{ Hunter value } \\
\hline L & 75.54 & 74.86 & 75.57 & 74.86 & 77.13 & 0.414 & 0.74 & 0.99 \\
\hline a & 3.53 & 4.41 & 4.34 & 4.21 & 3.35 & 0.189 & 0.19 & 0.51 \\
\hline$b$ & 6.91 & 7.96 & 7.92 & 7.73 & 7.16 & 0.179 & 0.51 & 0.37 \\
\hline
\end{tabular}

SEM, standard error of mean; Lin, linear; Quad, quadratic.

1) Least squares means for 4 pigs per treatment.

2) CON, wheat $0 \%$; W15, wheat $15 \%$; W 30 , wheat $30 \%$; W 45 , wheat $45 \%$; W60, wheat $60 \%$.

${ }^{3)} L$, luminance or brightness (varies from black to white); $a$, red and green component (+a: red, -a: green); b, yellow and blue component (+b: yellow, -a: blue).

[5] which may discriminated against by many consumers. Han et al [5] reported that there was no significant difference between corn-based and wheat-based diets. Generally, wheat contains a lower content of carotenoid than corn so the wheat-based diet could produce a better quality of fat. However, our results and the results of other studies indicated that fat quality was not affected by feed ingredients.

\section{CONFLICT OF INTEREST}

We certify that there is no conflict of interest with any financial organization regarding the material discussed in the manuscript.

\section{ACKNOWLEDGMENTS}

This work was supported by Korea Institute of Planning and Evaluation for Technology in Food, Agriculture, Forestry and Fisheries (IPET) through Advanced Production Technology Development Program, funded by Ministry of Agriculture, Food and Rural Affairs (MAFRA) (313001-3).

\section{REFERENCES}

1. Hasha G. Livestock feeding and feed imports in the European UnionA decade of change. Electronic Outlook Report from the Economic Research Service United States Department of Agriculture. 2002.

2. Stein HH, Pahm AA, Roth JA. Feeding wheat to pigs. Swine Focus 2010;2:1-8.

3. Committee on Nutrient Requirements of Swine, National Research Council. Nutrient requirements of swine. 11th ed. Washington, DC: National Academy Press; 2012.

4. Jaworski NW, Lærke HN, Bach Knudsen KE, Stein HH. Carbohydrate composition and in vitro digestibility of dry matter and nonstarch polysaccharides in corn, sorghum, and wheat and coproducts from these grains. J Anim Sci 2015;93;1103-13.

5. Han Y, Soita JW, Thacker PA. Performance and carcass composition of growing-finishing pigs fed wheat or corn-based diets. Asian-Australas J Anim Sci 2005;18:704-10.

6. Cromwell GL. Impacts of genetically modified, low-phytate corn and soybean meal and transgenic pigs possessing salivary phytase on phosphorus excretion. New Developments Regarding the Pig's Need for Vitamins E, A, and C. 2002;5:59.

7. Phillippy BQ. Susceptibility of wheat and Aspergillus niger phytases to inactivation by gastrointestinal enzymes. J Agri Food Chem 1999; 47:1385-8.

8. FAO Cereal Supply and Demand Brief [Internet]. Rome, Italy: [cited 2015 May], p. 1. Available from: http://www.fao.org/worldfoodsituation/ $\mathrm{csdb} / \mathrm{en} /$

9. Committee on Nutrient Requirements of Swine, National Research Council. Nutrient requirements of swine. 10th ed. Washington, DC: National Academy Press; 1998.

10. Horwitz W, Latimer Jr. GW; AOAC Official methods of Analysis of AOAC International. 18th ed.. Gaithersburg, MD: AOAC International; 2005.

11. Seerley RW, Vandergrift WL, Hale OM. Effect of particle size of wheat on performance of nursery, growing and finishing pigs. J Anim Sci 1988;66:2484-9.

12. Lunen TV, Schulze H. Influence of Trichoderma longibrachiatum xylanase supplementation of wheat and corn based diets on growth performance of pigs. Can J Anim Sci 1996;76:271-3.

13. Carr SN, Rincker PJ, Killefer J, et al. Effects of different cereal grains and ractopamine hydrochloride on performance, carcass characteristics, and fat quality in late-finishing pigs. J Anim Sci 2005;83:223-30.

14. Bruneau CD, Chavez ER. Dietary preferences for cereals of nursing and weaned piglets. Livest Prod Sci 1995;41:225-31.

15. Mavromichalis I, Hancock JD, Senne BW, et al. Enzyme supplementation and particle size of wheat in diets for nursery and finishing pigs. J Anim Sci 2000;78:3086-95.

16. Pedersen C, Boersma MG, Stein HH. Digestibility of energy and phosphorus in ten samples of distillers dried grains with solubles fed to growing pigs. J Anim Sci 2007;85:1168-76.

17. Sauer WC, Stothers SC, Parker RJ. Apparent and true availabilities of amino acids in wheat and milling by-products for growing pigs. Can J Anim Sci 1977;57:775-84.

18. Woyengo TA, Sands JS, Guenter W, Nyachoti CM. Nutrient digestibility and performance responses of growing pigs fed phytase-and xylanasesupplemented wheat-based diets. J Anim Sci 2008;86:848-57.

19. Lyberg K, Andersson HK., Sands JS, Lindberg JE. Influence of phytase and xylanase supplementation of a wheat-based diet on digestibility and performance in growing pigs. Acta Agric Scand 2008;58:146-51. 
20. Powell JJ, Whitehead MW, Lee S. Mechanisms of gastrointestinal absorption: dietary minerals and the influence of beverage ingestion. Food Chem 1994;51:381-8.

21. Graham H, Hesselman K, Aman P. The influence of wheat bran and sugar-beet pulp on the digestibility of dietary components in a cerealbased pig diet. J Nutr 1986;116:242-51.

22. Choct M, Annison G. Anti-nutritive activity of wheat pentosans in poultry diets. Br Poult Sci 1990;31:809-19.

23. Noblet J, Perez JM. Prediction of digestibility of nutrients and energy values of pig diets from chemical analysis. J Anim Sci 1993;71:3389-98.

24. Kil DY, Sauber TE, Jones DB, Stein HH. Effect of the form of dietary fat and the concentration of dietary neutral detergent fiber on ileal and total tract endogenous losses and apparent and true digestibility of fat by growing pigs. J Anim Sci 2010;88:2959-67.

25. Bergsjø B, Langseth W, Nafstad I, Jansen JH, Larsen HJS. The effects of naturally deoxynivalenol-contaminated oats on the clinical condition, blood parameters, performance and carcass composition of growing pigs. Vet Res 1993;17:283-94.

26. Matthews JO, Southern LL, Pontif JE, Higbie AD, Bidner TD. Interactive effects of betaine, crude protein, and net energy in finishing pigs.
J Anim Sci 1998;76:2444-55.

27. Dänicke S, Valenta H, Klobasa F, et al. Effects of graded levels of Fusarium toxin contaminated wheat in diets for fattening pigs on growth performance, nutrient digestibility, deoxynivalenol balance and clinical serum characteristics. Arch Anim Nutr 2004;58:1-17.

28. Miller ER, Ullre DE, Ackerma I, et al. Swine hematology from birth to maturity. I. Serum protein. J Anim Sci 1961;20:31-5.

29. Eggum, BO. Blood urea measurement as a technique for assessing protein quality. Br J Nutr 1970;24:983-8.

30. Baxmann AC, Ahmed MS, Marques NC, et al. Influence of muscle mass and physical activity on serum and urinary creatinine and serum cystatin C. Clin J Am Soc Nephrol 2008;3:348-54.

31. Okrouhla M, Stupka R, Citek J, et al. Effect of lean meat proportion on the chemical composition of pork. Czech J Food Sci 2008;26:464-9.

32. Brewer MS, McKeith FK. Consumer-rated quality characteristics as related to purchase intent of fresh pork. J Food Sci 1999;64:171-4.

33. Maganhini MB, Mariano B, Soares AL, et al. Meats PSE (Pale, Soft, Exudative) and DFD (Dark, Firm, Dry) of an industrial slaughterline for swine loin. Ciênc Tecnol Aliment, Campinas, 2007;27:69-72. 